\title{
PERGUB BALI NOMOR 97 TAHUN 2018 DALAM PARADIGMA ETIKA EKOSENTRISME
}

\author{
I Gst. Ngr. Agung Krisna Aditya \\ Program Studi Sosiologi \\ Fakultas Ilmu Sosial dan Ilmu Politik \\ Univeritas Udayana \\ Email: krisnaditya25@unud.ac.id
}

\begin{abstract}
ABSTRAK
Pembatasan penggunaan plastik sekali pakai melalui Peraturan Gubernur Bali nomor 97 tahun 2018 dijelaskan melalui etika ekosentrisme bertujuan untuk menganalisis aspek normatif, kebijakan dan gaya hidup yang bersahabat dengan ekologi. Metode analisis wacana kritis digunakan untuk memperoleh kognisi sosial sebagai penghubung struktur meso antara teks dengan konteks. Cerminan paradigma ekosentrisme diwujudkan dalam Pasal 2 mengenai pedoman Pemerintah dalam merumuskan kebijakan teknis. Platform aksi filosofi ekosofi Arne Naess dijelaskan dalam 8 platform yang relevan dengan pasal di dalam Pergub nomor 98 Tahun 2018. Konteks normatif Peraturan Gubernur mengkonstruksikan kesadaran dan praktek kolektif publik yang bertujuan untuk menghormati nilai ekologis.
\end{abstract}

Kata Kunci: Peraturan Gubernur, plastik sekali pakai, ekosentrisme

\begin{abstract}
Restrictions on disposable plastic use through the Bali Governor Regulation Number 97 Year 2018 explained through Ecocentrism ethics aimed at analyzing the normative aspects, policies and lifestyles that are friendly with ecology. The Critical Discourse Analysis method is used to acquire social cognition as a liaison of the meso structure between text and context. A reflection of the ecocentrism paradigm is embodied in article 2 of the Government's assessment of formulating technical policies. The Ecological philosophy action platform from Arne Naess is described in the 8 platforms relevant to the chapters of Governor's Regulation Number 98 Year 2018. The normative context of the Governor's Regulation is the construction of public collective awareness and practice as aim to respecting ecological values.
\end{abstract}

Keywords: Rules of governor, disposable plastic, ecocentrism 


\section{PENDAHULUAN}

Produksi sampah di Bali mencapai 4.281 ton per hari dimana 11 persen diantaranya mengalir hingga laut (Bali Partnership dalam Mongabay, 2018). Jumlah sampah setiap tahun telah mencapai 1,5 juta dengan persentase 52 persen sampah tidak dikelola dibandingkan 48 persen yang dikelola. Wilayah sumber sampah berasal dari Denpasar, Badung dan Gianyar dengan mengandalkan TPA Suwung sebagai tempat pembuangan akhir. Data tersebut adalah hasil riset kolaboratif Bali Partnership antara Pemerintahan Norwegia, Universitas Udayana, Universitas Leed Inggris, Pemerintah Provinsi Bali dan lembaga konsultan Systemiq (Muhajir dalam Mongabay, 2018).Peningkatan jumlah sampah tidak bisa dilepaskan dari jumlah populasi. Jumlah penduduk Bali pada tahun 2017 sebanyak 4,2 juta ditambah oleh kehadiran wisatawan domestik sebanyak 10 juta dan 6,4 juta di tahun yang sama. Kota Denpasar menjadi penyumbang terbesar timbulan sampah di Bali (Dinas Lingkungan Hidup Bali dalam IDN Times, 2018). Jumlah penduduk Kota Denpasar mencapai 880.600 jiwa menghasilkan timbulan sampah mencapai 3.719 meter kubik per hari. Kabupaten Klungkung menempati posisi kedua dengan timbunan sampah mencapai 2.893 meter kubik per hari. Kabupaten Buleleng berada di posisi ketiga dengan 1.923 meter kubik.

Kabupaten Gianyar dengan 1.498 meter kubik, Kabupaten Jembrana 1.005 meter kubik, Kabupaten Tabanan 866 meter kubik, Kabupaten Badung 723 meter kubik, Kabupaten Bangli 559 meter kubik, dan Kabupaten Karangasem dengan 162 meter kubik per hari. Jenis sampah yang dihasilkan di Bali terbanyak adalah sampah organik sebesar 60 persen, sampah plastik 20 persen, kertas 11 persen, besi 2 persen, gelas 2 persen dan lain-lain 5 persen (Mongabay, 2018). Sampah plastik per bulan Desember 2018 telah mencapai 30 persen dari keseluruhan sampah anorganik (Forum Komunitas Hijau dalam Beritabali.com, 2018). Pemerintah Daerah Provinsi Bali menindaklanjuti permasalahan sampah plastik melalui Peraturan Gubernur Provinsi Bali Nomor 97 Tahun 2018 tentang Pembatasan Penggunaan Timbulan Sampah Plastik Sekali Pakai. Gubernur Bali menyatakan ada tiga bahan yang terbuat dari atau 
mengandung bahan dasar plastik yang dilarang yaitu kantong plastik, polysterina (styrofoam) dan sedotan plastik (Balipost, 2018).

Peraturan Gubernur telah diimplementasikan dalam rentang waktu 1 tahun sejak diterbitkan pada tanggal 24 Desember 2018. Pembatasan penggunaan plastik sekali pakai melalui Peraturan Gubernur Bali nomor 97 tahun 2018 dianalisis menggunakan paradigma etika ekosentrisme bertujuan untuk menganalisis aspek normatif, kebijakan dan gaya hidup yang bersahabat dengan ekologi. Ekosistem yang dimaksudkan tidak hanya terbatas pada ekosistem makhluk hidup sebagaimana menjadi paradigma biosentrisme. Etika lingkungan ekosentrisme menekankan keterkaitan seluruh organisme (makhluk hidup) dan anorganisme (abiotis) dalam ekosistem. Hal demikian sejalan dengan tujuan pembatasan sampah plastik sekali pakai untuk menjaga kesucian, keharmonisan, keselarasan dan keseimbangan ekosistem dan mengurangi resiko yang ditimbulkan modernisasi sebagai hasil dari paradigma antroposentrisme. Hasil analisis ini bermanfaaat secara praktis untuk pemerintah Provinsi Bali sebagai pemrakarsa peraturan, kesadaran masyarakat umum menjaga lingkungan dan mendorong kajian lebih banyak oleh akademisi khususnya mengenai etika ekosentrisme sebagai manfaat teoritis.

Penelitian terdahulu berkaitan dengan Pergub Bali Nomor 97 Tahun 2018 (Suwendra dan Suharta, 2019: 11) dengan fokus kajian pada alternatif pengganti plastik sekali pakai berdasarkan kajian hukum normatif dari Pasal 4 ayat 2. Penelitian kedua mengenai komunikasi sosial dengan tujuan sosialisasi penetapan kebijakan Gubernur mengenai timbulan sampah plastik sekali pakai (Putri, 2019: 44) telah meningkatkan kesadaran masyarakat. Penelitian ketiga mengenai pengurangan sampah plastik yang diatur dalam Peraturan Walikota Denpasar Nomor 36 tahun 2018 (Abhiseka dan Suharta, 2019: 10) belum efektif dilaksanakan di pasar tradisional. Perbedaan karya tulis ini dibandingkan penelitian terdahulu terdapat pada fokus analisis yang menggunakan teori Ekosentrisme dari Arne Naess (Keraf, 2002: 75). Penelitian 
terdahulu yang menggunakan Pergub Bali dan Peraturan Walikota sebagai dasar dalam mengurangi penggunaan sampah plastik terbatas dalam metode hukum empiris. Teori Ekosentrisme mencakup keberlangsungan komunitas ekologis biotis dan abiotis secara keseluruhan. Paradigma ekosentrisme tidak terbatas hanya dari peraturan sebagai produk antisipatif pasca pencemaran lingkungan. Paradigma ekosentrisme mengevaluasi pencemaran dari sudur pandang biosferik, kehidupan secara keseluruhan di setiap spesies dan sistem.

\section{METODE PENELITIAN}

Metode penelitian menggunakan Analisis Wacana Kritis (Critical Discourse Analysis/CDA) yang dikembangkan oleh Teun A. van Dijk. Penelitian atas wacana tidak cukup pada teks, tetapi juga harus dilihat praktik produksinya. Model dari analisis van Dijk (Eriyanto, 2012: 225) tidak hanya memandang struktur mikro dan struktur makro, tetapi juga struktur meso yang menghubungkan teks dan konteks, yaitu kognisi sosial. Dimensi teks melihat bagaimana struktur teks dan strategi wacana yang dipakai untuk menegaskan suatu tema tertentu. Kemudian dimensi kognisi sosial mempunyai dua arti. Pertama, kognisi sosial menunjukkan bagaimana proses teks diproduksi. Kedua, kognisi sosial menggambarkan penyebaran nilai. Dimensi terakhir yaitu konteks sosial dalam mempelajari bangunan wacana yang berkembang dalam masyarakat mengenai suatu masalah tertentu (Eriyanto, 2012, p.222-224).

Subjek penelitian ini adalah Peraturan Gubernur Bali Nomor 97 Tahun 2018 tentang Pembatasan Timbulan Sampah Plastik Sekali Pakai. Objek penelitian ini adalah wacana ekosentrisme dalam Pergub Bali Nomor 97 Tahun 2018. Unit analisis penelitian ini adalah teks berupa kata dan kalimat yang tertulis dalam bentuk Landasan Hukum, Bab dan Pasal dalam Pergub Bali Nomor 97 Tahun 2018. Unit analisis diperoleh dari pengunduhan dokumen Peraturan Gubernur di situs daring Jaringan Dokumentasi Informasi Hukum Pemerintah Provinsi Bali (Gubernur Bali, 2018). 
Teknik analisis wacana van Dijk terbagi dalam tiga dimensi analisis, yaitu struktur teks, kognisi sosial, dan analisis sosial (Eriyanto, 2012, p.229-274).

\section{HASIL DAN PEMBAHASAN}

Peraturan Gubernur Nomor 97 Tahun 2018 ditetapkan pada tanggal 21 Desember 2018 (Biro Hukum: 2018). Peraturan Gubernur mengenai Pembatasan Timbulan Sampal Plastik Sekali Pakai terdiri dari 12 Bab dan 26 Pasal. Pelaksanaan Peraturan Gubernur Nomor 97 Tahun 2018 sebagai pertimbangan untuk melaksanakan ketentuan Pasal 12 ayat (3) dan Pasal 12 ayat (2) Peraturan Daerah Provinsi Bali Nomor 5 tahun 2011 tentang Pengelolaan Sampah. Sampah yang diatur berjenis sampah rumah tangga, sampah sejenis rumah tangga dan sampah spesifik mengandung bahan berbahaya dan beracun. Tujuan pengelolaan sampah untuk menjaga kelestarian fungsi lingkungan hidup dan kesehatan masyarakat sesuai dengan etika ekosentrisme.

Pandangan antroposentris menurut ekosetrisme dinilai tidak ramah dan tidak bijak megatur hubungan manusia dengan alam. Krisis ekologi sebagai akibat dari hubungan manusia terhadap alam disebabkan faktor fundamental dan filosofis (Susilo, 2009: 111). Teori gerakan lingkungan selama ini dinilai hanya sebagai gerakan lingkungan dangkal oleh Arne Naess. Perubahan yang dibutuhkan bersifat fundamental dan revolusioner menyangkut transformasi cara pandang dan nilai, dari segi pribadi hingga budaya yang mempengaruhi struktur dan kebijakan ekonomi dan politik (Keraf, 2002: 82). Ekosentrisme sebagai teori etika lingkungan dikenal dengan Deep Ecology atau Ekologi Dalam (Naess dalam Keraf, 2002: 76). Etika lingkungan hidup yang dikembangkan Ekologi Dalam sebagai sebuah etika praktis, sebagai sebuah gerakan.

Paradigma ekosentrisme dalam Pergub Nomor 97 Tahun 2018 dijelaskan pada Pasal 2 ayat (1) hingga ayat (7) mengenai tujuan sebagai pedoman Pemerintah dalam 
perumusan kebijakan teknis di bidang Pembatasan Timbulan Sampah Plastik Sekali Pakai (Pergub, 2018). Pelaksanaan tujuan yang dimaksudkan dilakukan dengan cara:

1. Menjaga kesucian, keharmonisan, keselarasan dan keseimbangan lingkungan hidup

2. Menjamin pemenuhan dan perlindungan hak atas lingkungan hidup yang baik dan sehat bagi masyarakat akibat dampak buruk dari penggunaan plastik sekali pakai

3. Mencegah pencemaran dan/atau kerusakan lingkungan yang diakibatkan oleh penggunaan plastik sekali pakai

4. Menjamin dan menjaga kelangsungan kehidupan makhluk hidup dan kelestarian ekosistem

5. Menjamin keselamatan, kesehatan dan kehidupan masyarakat dari ancaman pencemaran dan/atau kerusakan lingkungan hidup, yang disebabkan oleh penggunaan plastik sekali pakai

6. Menjamin generasi masa depan untuk tidak tergantung pada penggunaan plastik sekali pakai, untuk mencapai kualitas hidup yang lebih baik

7. Membangun partisipasi masyarakat untuk berperan serta dalam perlindungan lingkungan hidup

Tujuan pelaksanaan Pergub Nomor 97 Tahun 2018 memiliki keterkaitan dengan platform aksi Ekologi Dalam (Deep Ecology) sebagai sebuah gerakan atau aksi nyata di lapangan. Filsafat ekosofi (ecosophy) yang digunakan Arne Naess sebagai gambaran kearifan mengatur hidup selaras dengan alam sebagai sebuah rumah tangga dalam arti luas (Susilo, 2009: 117). Keterkaitan hubungan manusia dengan lingkungan hidup sebagai sebuah kearifan dan menjaga alam sebagai sebuah rumah tangga yang mempunyai nilainya sendiri. Platform yang dirumuskan Arne Naess ditujukan agar perubahan tidak hanya terbatas pada proses politik tetapi yang terpenting adalah perubahan cara pandang, mental, sikap, perilaku dan gaya hidup. 
Ekologi Dalam mencari pandangan holistik dari dunia dan tidak terpisahkan dari ekosistem dan fungsi keseluruhannya. Pola hidup arif dan menjaga alam sebagai sebuah rumah tangga bersumber dari kearifan bahwa segala sesuatu berasal dari alam semesta memiliki nilainya tersendiri (Naess, 1995: 95). Nilai manusia sebagaimana paradigma antroposentris hanya sebagian dari keseluruhan nilai alam semesta. Kearifan membutuhkan perilaku dan tindakan konkret sebagai sebuah gerakan dan aksi nyata. Gerakan Ekologi Dalam (Deep Ecology) dirumuskan menjadi delapan platform aksi yang relevan dengan Pergub Bali Nomor 97 Tahun 2018 sebagai berikut:

1. Kesejahteraan dan perkembangan kehidupan manusia dan makhluk bumi di bumi ini mempunyai nilai pada dirinya sendiri. Platform ini berkaitan dengan kepedulian dan sikap hormat mendalam atas nilai dari keseluruhan organisme di dalam ekosistem. Tujuan Peraturan Gubernur yang tercantum dalam Pasal 2 telah menunjukkan kepedulian dan sikap hormat mendalam terhadap kualitas kehidupan dari ancaman pencemaran plastik sekali pakai.

2. Kekayaan dan keanekaragaman bentuk kehidupan memberikan sumbangsih bagi pewujudan nilai dari perkembangan kehidupan manusia dan bukan manusia. Keanekaragaman mengimplikasikan pada keterkaitan berbagai bentuk kehidupan termasuk masyarakat adat yang telah dijelaskan pada Pasal 15. Desa Adat/Desa Pakraman sebagai kesatuan masyarakat hukum adat memiliki peranan dalam menjaga keanekaragaman hayati.

3. Pemenuhan kebutuhan vital manusia dengan tujuan mengenyampingkan kebutuhan jangka pendek. Pasal 13 ayat (1) menjelaskan hak masyarakat untuk menggunakan pengganti plastik sekali pakai dengan mengutamakan bahan/alat pengganti yang ramah lingkungan. Pemenuhan kebutuhan vital tercantum dalam Pasal 14 dengan tidak menggunakan plastik sekali pakai dan aktif melakukan pencegahan penggunaan plastik sekali pakai.

4. Perkembangan kebudayaan manusia sejalan dengan pertambahan jumlah penduduk. Krisis lingkungan berkaitan dengan kondisi demografis dan 
membutuhkan perubahan mendasar. Strategi jangka menengah sebagai perubahan mendasar dalam membatasi plastik sekali pakai dijelaskan pada Pasal 12 ayat (3) mengenai Rencana Aksi Daerah Pembatasan Timbulan Sampah Plastik Sekali Pakai.

5. Campur tangan manusia dengan menggunakan bahan kimia berbahaya hingga rekayasa genetika membahayakan keberlangsungan ekosistem. Bahan kimia yang dimaksudkan berjenis plastik sekali pakai seperti kantong plastik, sedotan plastik dan styrofoam (polysterina) sebagaimana dijelaskan dalam Pasal 1 ayat (9). Resiko dari penggunaan jenis sampah plastik dijelaskan pada Pasal 4 dan Pasal 5 mengenai timbulan sampah yang diukur dari volume/berat dan jenis sumber sampah pada satuan watku di wilayah tertentu.

6. Perubahan kebijakan untuk mempengaruhi struktur ekonomi, teknologi dan ideologi tercantum dalam penetapan Peraturan Gubernur Nomor 97 Tahun 2018 sebagai tindak lanjut dari kebijakan Peraturan Daerah Provinsi Bali Nomor 5 tahun 2011, Pasal 12 ayau (3) dan Pasal 13 ayat (2) tentang Pengelolaan Sampah. Peraturan diterapkan pada seluruh lembaga masyarakat yang dijelaskan pada Pasal 1 ayat (1) hingga ayat (8) yaitu Pemerintah Daerah; Pemerintah Provinsi, Gubernur, Walikota, Bupati; Perangkat Daerah; Lembaga Keagamaan; Desa Adat dan Lembaga Swasta.

7. Penghargaan atas perubahan kualitas kehidupan dari pelaksanaan ketentuan dalam Peraturan Gubernur dijelaskan pada Pasal 19 dan Pasal 20. Bentuk penghargaan yang diberikan berupa piagam penghargaan; bantuan dana pengelolaan sampah; bantuan modal usaha; bantuan sarana dan prasarana yang mendukung pelaksanaan program; hingga bantuan dana insentif Desa Adat/Desa Pakraman.

8. Setiap individu yang telah ditentukan pada Pasal 1 memiliki komitmen moral untuk melaksanakan ketentuan yang telah dijelaskan di dalam 26 butir Pasal sejak ditetapkan pada tanggal 21 Desember 2018. Ketentuan, penghargaan hingga sanksi administratif dikenakan kepada individu menyesuaikan dengan status sosial mereka di masyarakat. Pasal 25 menentukan produsen, distributor, pemasok 
pelaku usaha dan penyedia plastik sekali pakai untuk menyesuaikan usahanya hingga 6 bulan sejak diberlakukannya Peraturan Gubernur pada tanggal 21 Desember 2018.

Cara pandang gerakan ekologi tidak hanya diarahkan pada individu tetapi mempengaruhi setiap kebijakan publik tentang lingkungan (Suka, 2017: 40). Peraturan Gubernur Bali Nomor 97 tahun 2018 sebagai bentuk perjuangan Ekologi Dalam yang diupayakan melalui tindakan-tindakan praksis dari saluran politik. Norma yang dikampanyekan mempengaruhi setiap orang dan kelompok masyarakat sebagai gaya hidup baru yang menggunakan produk pengganti platik sekali pakai telah tercantum pada Pasal 11. Perubahan pola produksi dan konsumsi yang ramah lingkungan diwujudkan dengan pelarangan timbulan sampah plastik sekali pakai. Proses peralihan menuju bahan yang bisa digunakan berulang kali telah direncanakan pada Pasal 17 mengenai Pembinaan dan Pengawasan yang dilakukan oleh tim yang dibentuk langsung oleh Gubernur.

Proses pengambilan keputusan mengenai pembatasan penggunaan sampah plastik sekali pakai tidak boleh lepas dari pendangan nilai etika ekosentrisme. Kesewenangan perilaku manusia dalam menggunakan plastik sekali pakai akan menyebabkan ancaman terhadap keberlangsungan lingkungan beserta nilai yang terkandung di dalamnya. Prinsip demikian dibutuhkan dalam mengelola lingkungan yang mengutamakan kesejahteraan lingkungan hidup. Norma-norma moral objektif dengan mengutamakan tanggung jawab manusia menjagai interaksinya terhadap nonmanusia guna menjaga masa depan generasi selanjutnya (Chang, 2001: 22).

\section{KESIMPULAN}

Etika ekosentrisme menawarkan perspektif komprehensif dan holistik sebagai jawaban terhadap permasalahan ilmu konvensional yang bersifat positivistik, atomistik dan reduksionalistik. Masalah timbulan sampah plastik sekali pakai sebagai akibat dari etika antroposentris yang bertentangan dengan ekosentrisme diatur melalui Peraturan 
Gubernur nomor 97 Tahun 2018. Tanggung jawab tidak hanya dibebankan konsumen akhir tetapi seluruh masyarakat yang terlibat dalam timbulnya plastik sekali pakai untuk beralih menggunakan bahan pengganti yang bisa digunakan berulang dan ramah lingkungan. Kesadaran masyarakat dikonstruksikan bersama dengan nilai-nilai moral lingkungan melalui sosialisasi pembentukan kepribadian dan jiwa kosmis kesemestaan. Legitimasi pembatasan timbulan plastik sekali pakai melalui Peraturan Gubernur Bali Nomor 97 tahun 2018 tidak terbatas normatif dan utopis, tetapi membentuk kesadaran kolektif publik untuk mempraktekkan gaya hidup yang menghormati nilai moral ekologis.

\section{DAFTAR PUSTAKA}

Abhiseka, I., \& Suharta, N. (2019). Implementasi Peraturan Walikota Denpasar Nomor 36 Tahun 2018 Tentang Pengurangan Kantong Plastik. Kertha Negara: Journal Ilmu Hukum, 7(6), 1-13.

Chang, W. (2002). Moral Lingkungan Hidup. Yogyakarta: Kanisius

Devita, R. 2018. Gubernur Bali Keluarkan Pergub, Ini Tiga Bahan Plastik Yang Dilarang. Diakses tanggal 5 Januari 2020 di http://www.balipost.com/news/2018/12/24/64588/Gubernur-Bali-KeluarkanPergub,Ini...html

Eriyanto.(2012). Analisis Wacana: Pengantar Analisis Teks Media. Yogyakarta: LKiS. Gubernur Bali. (2018). Peraturan Gubernur Bali Nomor 97 Tahun 2018 Tentang Pembatasan Sampah Plastik Sekali Pakai. Jaringan Dokumentasi Informasi Hukum Pemerintah Provinsi Bali. Diakses tanggal 15 Januari 2020 di https://jdih.baliprov.go.id/produk-hukum/peraturan/abstrak/24688

Keraf, AS. (2002). Etika Lingkungan. Jakarta: Penerbit Buku Kompas

Muhajir, A. (2018). Inilah Data dan Sumber Sampah Terbaru di Bali. Diakses tanggal 5 Januari 2020 di https://www.mongabay.co.id/2019/07/02/inilah-data-dansumber-sampah-terbaru-di-bali/

Muliarta, IN. (2019). Tercatat 30\% Sampah Anorganik di Sungai di Denpasar Adalah Kantong Plastik. Diakses tanggal 5 Januari 2020 di https://news.beritabali.com/read/2019/01/16/201901160013/tercatat-30sampah-anorganik-di-sungai-di-denpasar-adalah-kantong-plastik

Naess, A. (1995). The Shallow and The Deep, Long-Range Ecology Movement. A Summary. Inquiry. 16,95-100 
Putri, N. (2019). Komunikasi Sosial Dalam Mensosialisasikan Penetapan Kebijakan Gubernur Bali Tentang Pembatasan Timbulan Sampah Plastik Sekali Pakai. Jurnal Nomosleca, 5(1).

Rosidin, I. (2018). 9 Ranking Kabupaten atau Kota Penghasil Sampah Tertinggi di Bali. Diakses tanggal 5 Januari 2020 di https://bali.idntimes.com/news/bali/imamrosidin/data-sampah-tertinggi-diprovinsi-bali/full

Suka, G. (2017). Teori Etika Lingkungan: Antroposentrisme Ekofeminisme Ekosentrisme. Denpasar: Udayana University Press

Susilo, RK. (2009). Sosiologi Lingkungan. Jakarta: Rajawali Press

Suwendra, P., \& Suharta, N. (2019). Alternatif Pengganti Plastik Sekali Pakai Pada Peraturan Gubernur Bali Nomor 97 Tahun 2018. Kertha Negara : Journal Ilmu Hukum, 7(8), 1-12 